\title{
Article \\ Impact of Cleft Palate Anastomosis in Cleft Lip and Palate Patients with Coexisting Cleft Lip Anastomosis Scar Based on Cephalometric Measurements
}

\author{
Natalia Kaczorowska *(D) and Marcin Mikulewicz (D)

\begin{abstract}
Department of Dentofacial Orthopedics and Orthodontics, Division of Facial Abnormalities, Wroclaw Medical University, Krakowska 26, 50-425 Wroclaw, Poland; marcin.mikulewicz@umw.edu.pl

* Correspondence: nataliakaczorowskaa@gmail.com
\end{abstract}

Citation: Kaczorowska, N.; Mikulewicz, M. Impact of Cleft Palate Anastomosis in Cleft Lip and Palate Patients with Coexisting Cleft Lip Anastomosis Scar Based on Cephalometric Measurements. Appl. Sci. 2022, 12, 1104. https:// doi.org/10.3390/app12031104

Academic Editor: Yong-Deok Kim

Received: 30 November 2021

Accepted: 18 January 2022

Published: 21 January 2022

Publisher's Note: MDPI stays neutral with regard to jurisdictional claims in published maps and institutional affiliations.

Copyright: (C) 2022 by the authors. Licensee MDPI, Basel, Switzerland. This article is an open access article distributed under the terms and conditions of the Creative Commons Attribution (CC BY) license (https:// creativecommons.org/licenses/by/ $4.0 /)$.
Featured Application: This paper aims to indicate which cephalometric parameters should be specifically analyzed in patients with cleft lip and palate and with cleft lip and which ones should be targeted by orthodontic treatment.

\begin{abstract}
Background: This article focuses on examining components affecting the overbite, overjet, and the effect of palate surgery on craniofacial morphology with a concomitant cleft lip fusion scar, and a comparison of patients who had only a cleft lip fusion scar. Patients with unilateral cleft lip (UCL) and patients with unilateral cleft lip and palate (UCLP) were included in the study. We aimed to find if cephalometric parameters were significantly different in these groups. (2) Material and methods: The study group consisted of a lateral cranial radiograph of patients with UCLP $(n=30)$ and UCL $(n=30)$. Cephalometric radiographs were saved electronically, and cephalometric analysis was performed using a computer program. (3) Results: We observed that a statistically significant higher degree of maxillary prognathism occurred in the UCL than in the UCLP. We observed the anterior position of the upper lip in relation to E-line in patients with cleft lip. (4) Conclusions: The results present the effect of cleft palate surgery on further forward growth of the maxilla. There was a decreased ANB angle present in the skeletal class II in patients with UCL and UCLP. The SNB angle was not increased, and the reverse overjet was due to the rectroclination of the upper incisors and protruded lower incisors.
\end{abstract}

Keywords: cleft lip; cleft lip and palate; cephalometric measurements; orthodontics

\section{Introduction}

Orofacial clefts are the most common head and neck congenital malformation [1] and are the second most common congenital abnormality in children, after heart defects [2,3]. Unilateral cleft lip and palate (UCLP) accounts for $45 \%$ of all clefts; the second most frequent is unilateral cleft lip (UCL), which involves $25 \%$ of patients [4]. Both groups of patients require complex multidisciplinary care [5].

Lack of soft and hard tissue continuity contributes to craniofacial deformities. These include skeletal abnormalities, such as abnormal development of the maxillary bones, frontal, zygomatic, and orbital bones, as reported in a study conducted in Taiwan [6]. However, it is noteworthy that there was no statistical difference in the ossification time of the SphenoOccipital Synchondrosis in patients with UCLP compared to patients without cleft [7].

Researchers from Japan have reported the occurrence of maxillary retrusion and a steeper mandible in patients with unoperated UCLP [8]. Moreover, the occurrence of hypodontia, hyperdontia, and disturbances in the size, shapes and position of the teeth have been confirmed within the dentition. The absence of permanent tooth buds concerns $24 \%$ of patients with clefts in the craniofacial area. Almost every patient in this cleft lip and palate group has a delayed eruption of permanent teeth, as described in the study by Polish 
researchers [9]. Authors from Sweden point out the occurrence of dental abnormalities, including infraocclusion of primary molars and transposition in patients with UCLP [10]. Another study, conducted in Italy, concerns the three-dimensional assessment of the jaw and palate of patients with UCLP. Attention is drawn to the reduced surface area and volume of the palate, the reduced intercanine width, and the insignificantly reduced intermolar dimension in the superior arch. Moreover, according to studies carried out in Finland, hypodontia of the lateral incisor in patients with UCLP delays the dental age [11].

The authors decided to conduct this study because of the discrepancy in previous results from other researchers.

It is widely believed that surgical treatment of cleft palate is the main cause of tissue scarring and the reason for reduced i.a. forward maxilla dimension [12]. This is also supported by studies conducted on patients of Caucasian origin with UCLP [13] and studies by Bin Ye and coauthors [14]. This is contradicted by the results of other authors who did not present reduced maxilla growth in patients with only cleft palate fusion [15]. Moreover, patients with unoperated cleft palate demonstrate reduced maxillary length and retruded maxillary position relative to the cranial base $[16,17]$.

Further conflicting reports concern the substrate of the reverse overbite in operated UCLP patients. Some studies report anterior growth of the mandible as the cause of reverse overjet [18], while other authors report that individuals with cleft lip and palate had a significantly shorter maxillary length [19].

We aimed to perform a cephalometric analysis in patients with cleft lip and with cleft lip and palate. The article focuses mainly on examining components affecting the overbite, overjet, and the effect of palate surgery on craniofacial morphology with a concomitant cleft lip fusion scar and a comparison for patients who had only a cleft lip fusion scar. Patients with UCL and patients with UCLP were included in the study. Both groups were patients treated with surgery, which included cleft lip repair and cleft lip and palate repair, respectively.

The following statements were made as the research hypothesis:

(1) SNA angle is smaller in UCLP patients than in UCL patients.

(2) SNB angle reaches a similar value in patients with UCLP and UCL.

(3) U1 to NA ( $\mathrm{mm})$ is smaller in UCLP patients than UCL patients.

(4) Eversion of the upper lip is observed in UCL patients.

\section{Materials and Methods}

\subsection{Materials}

Sample size analysis was performed in Statistica 13 (TIBCO Software Inc.). Based on the available results, differences between the two groups (groups: UCL vs. UCLP) were evaluated. The mean and standard deviation of SNA scores in both groups were used in the sample size estimation analysis. The estimated sample size was calculated based on the $t$-test for means of two samples ( $t$-test for independent samples). Parameters: the mean in the $\mathrm{PW}$ group was $79.45(\mathrm{SD}=4.19)$; the mean in the $\mathrm{W}$ group was $83.62(\mathrm{SD}=5.60)$; and the alpha level was set at 0.05 and the power of the test was set at 0.8 . It was also assumed that there was no correlation of the variables evaluated and the two-sided null hypothesis was accepted. Based on the parameters, an estimated sample size of 30 patients in each group was obtained.

The study group consisted of a lateral cranial radiograph of patients with unilateral cleft lip and palate $(n=30)$ and patients with unilateral cleft lip $(n=30)$. All of them were patients of the Department of Maxillofacial Orthopaedics and Orthodontics, Division of Facial Abnormalities, Wroclaw Medical University in Poland. The inclusion criterion was the diagnosis of unilateral cleft hard palate with cleft lip (diagnosis code Q37.1 according to ICD10) who underwent anastomosis cleft lip and palate surgery in childhood. The second group comprised children with a diagnosis of unilateral cleft lip (diagnosis code Q36.9 according to ICD10) who underwent cleft lip anastomosis surgery. All patients were operated on in the same hospital. The cleft lip anastomosis procedure in UCL and UCLP 
patients was performed using the same method. Patients included in the study were between age 8 years 10 months to 10 years 7 months. The exclusion criteria were prior orthodontic intervention and non-operative UCL/UCLP patients. All patients with UCL and UCLP had upper lateral incisors.

The retrospective study included lateral cranial radiographs taken as standard for orthodontic diagnosis between 2016 and 2021.

\subsection{Methods}

All lateral cranial radiographs were analyzed by a single author of this study. The cephalometric radiographs were saved electronically, and cephalometric analysis of each radiograph performed using a Webceph software. All cephalometric points were applied manually. During the measurements, 33 measurement points were marked. The results of 10 angles, 3 reference lines, and 2 segments were included in the study. Example measurements are shown in Figure 1.

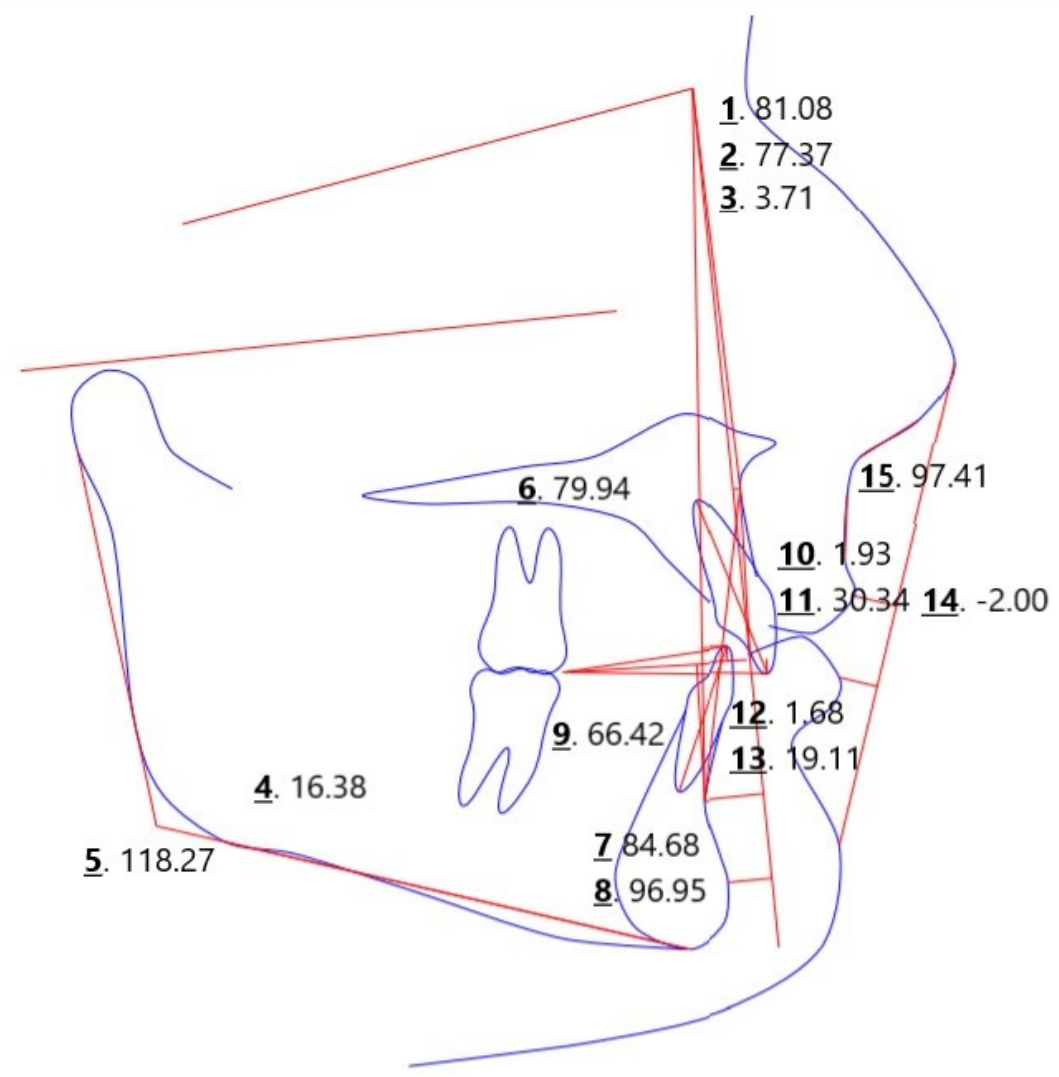

Figure 1. Example measurements included in the study. 1. SNA; 2. SNB; 3. ANB; 4. FMA; 5. Gonial Angle; 6. APDI; 7. ODI; 8. IMPA; 9. L1 to LOP; 10. U1 to NA (mm); 11. U1 to Na (deg); 12. L1 to NB (mm); 13. L1 to NB (deg); 14. Upper lip to E-plane;:15. Nosolabial angle.

The analysis considered the following parameters: SNA describes the anterior-posterior position of point A (the point lying deepest on the anterior outline of the alveolar process) in relation to the anterior cranial fossa, SNB describes the anterior-posterior position of point B (the point lying deepest on the anterior outline of the alveolar portion of the mandible) in relation to the anterior cranial fossa, ANB describes the position of mandible in relation to maxilla, FMA included between lines FH (corresponds to Frankfurt horizontal plane-passes through points orbitale and tragion) and GoGn (line of mandibular body defined by points Gonion and Gnathion), Gonial angle, ODI stands for overbite depth indicator, APDI stands for anteroposterior dysplasia indicator, IMPA located between long axis of lower incisor tooth and GoGn line, U1 to NA (mm), and U1 to NA (deg) determines anteroposterior 
position of upper incisor teeth in relation to maxillary base, L1 to NB (mm) and L1 to NB (deg) are the anteroposterior positions of the lower incisors in relation to the base of the mandible, and L1 to LOP is the anteroposterior positions of the lower incisors in relation to the lower occlusal plane, the upper lip to E-plane is the location of the upper lip in relation to the aesthetic line that passes through the tip of the nose and chin (upper lip should be $3 \mathrm{~mm}$ apart), and the Nasolabial angle.

\subsection{Statistical Analysis}

Statistical analysis was performed using Statistica 13 software (TIBCO, 3307 Hillview Avenue Palo Alto, CA 94304, USA). Arithmetic means, medians, standard deviations, quartiles, and range of variability (extreme values) were calculated for measurable variables. All study variables of quantitative type were checked by Shapiro-Wilk test to determine the type of distribution. Comparison of results between the "cleft lip and palate" group and the "cleft lip" group was assessed using the $t$-test for independent samples or U-Mann-Whitney depending on the assumptions met. In addition, Spearman rank correlation analysis or Pearson correlation analysis was performed depending on the assumptions met. An $\alpha=0.05$ level was used for all comparisons.

\section{Results}

A comparison of the results obtained in the cleft lip and palate group and the cleft lip group for SNA, SNB, and ANB parameters is presented in Table 1. It was observed that a statistically significant higher degree of maxillary prognathism (SNA) occurred in the cleft lip group $(\bar{x}=82.9$ degrees; $S D=4.0$ degrees $)$ than in the cleft lip and palate group $(\bar{x}=79.1$ degrees; $S D=4.0$ degrees $)(p<0.001)$. In addition, there were statistically significant differences in mandibular versus maxillary (ANB) position between the study groups $(p=0.008)$. The mean ANB score for the lip and palate group was 2.13 degrees $(\mathrm{SD}=2.7$ degrees $)$ and for the lip group was 4.03 degrees $(\mathrm{SD}=2.7$ degrees) (Table 1$)$.

Table 1. Comparison of SNA, SNB, and ANB scores between cleft lip and palate and cleft lip groups.

\begin{tabular}{|c|c|c|c|c|c|c|c|c|c|c|c|c|c|c|c|}
\hline & \multicolumn{14}{|c|}{ Group } & \multirow{3}{*}{$p$-Value } \\
\hline & \multicolumn{7}{|c|}{ Cleft Lip and Palate $(n=30)$} & \multicolumn{7}{|c|}{ Cleft Lip $(n=30)$} & \\
\hline & $\overline{\mathbf{x}}$ & $\mathrm{Me}$ & Min & Max & Q1 & Q3 & SD & $\overline{\mathbf{x}}$ & $\mathrm{Me}$ & Min & Max & Q1 & Q3 & SD & \\
\hline SNA & 79.1 & 79.0 & 69.7 & 86.4 & 75.9 & 81.5 & 4.0 & 82.9 & 82.8 & 71.1 & 92.7 & 81.0 & 84.9 & 4.0 & $<0.001 *$ \\
\hline SNB & 76.9 & 76.7 & 69.5 & 86.8 & 74.6 & 79.2 & 4.3 & 78.9 & 78.8 & 74.1 & 86.3 & 76.7 & 81.0 & 3.1 & $0.053^{* *}$ \\
\hline ANB & 2.13 & 2.56 & -2.33 & 7.41 & -0.11 & 4.07 & 2.7 & 4.03 & 4.30 & -3.01 & 9.91 & 2.53 & 5.67 & 2.7 & $0.008^{* *}$ \\
\hline
\end{tabular}

$\mathrm{n}$-number of persons; $\bar{x}-$ mean; Me-median; Min-minimum value; Max-maximum value; $Q 1-$ lower quartile; Q3 - upper quartile; SD—standard deviation; * U-Mann-Whitney test; ${ }^{* *}$ independent samples $t$-test.

Table 2 presents the comparison of FMA, Gonial angle, APDI, and ODI scores between the study groups. Statistically significant differences were observed for the ODI parameter $(p=0.046)$, with the cleft lip and palate group having a mean score of 74.0 points $(\mathrm{SD}=8.8$ points $)$ and the cleft lip group having a mean score of 78.2 points $(\mathrm{SD}=7.0$ points $)$ (Table 2). Otherwise, no statistically significant differences were observed.

A comparison of IMPA, U1 to NA (mm), U1 to NA (deg), L1 to NB (mm), and L1 to NB (deg) scores relative to the study groups is presented in Table 3. Statistically significant differences were observed for the IMPA parameter $(p=0.001)$, the mean score for the cleft lip and palate group was 88.2 points ( $S D=7.9$ points), and for the cleft lip group the mean score was 94.7 points ( $\mathrm{SD}=6.8$ points). Additionally, statistically significant differences were observed for the parameter L1 to LOP $(p=0.004)$, the mean score in this case for the cleft lip and palate group was 72.8 points $(\mathrm{SD}=7.8$ points) and for the cleft lip group the mean was 67.3 points ( $\mathrm{SD}=6.3$ points). The results were statistically significantly different for the parameter L1 to NB (deg) $(p=0.004)$, the mean score for the cleft lip and palate group was $18.1 \mathrm{deg}(\mathrm{SD}=6.6 \mathrm{deg})$ and for the cleft lip group the mean score was 
$23.1 \mathrm{deg}(\mathrm{SD}=6.5 \mathrm{deg})$. Otherwise, no statistically significant differences $(p>0.05)$ were observed (Table 3).

Table 2. Comparison of FMA, Gonial angle, APDI, and ODI scores between the lip and palate group and the lip group.

\begin{tabular}{|c|c|c|c|c|c|c|c|c|c|c|c|c|c|c|c|}
\hline & \multicolumn{14}{|c|}{ Group } & \multirow{3}{*}{$p$-Value * } \\
\hline & \multicolumn{7}{|c|}{ Cleft Lip and Palate $(\mathrm{n}=30)$} & \multicolumn{7}{|c|}{ Cleft Lip $(n=30)$} & \\
\hline & $\overline{\mathbf{x}}$ & Me & Min & Max & Q1 & Q3 & SD & $\overline{\mathbf{x}}$ & $\mathrm{Me}$ & Min & $\operatorname{Max}$ & Q1 & Q3 & SD & \\
\hline FMA & 25.4 & 26.1 & 16.8 & 36.3 & 20.3 & 28.9 & 5.4 & 22.9 & 23.1 & 9.9 & 34.8 & 20.4 & 26.8 & 6.3 & 0.116 \\
\hline Gonial angle & 124.2 & 124.1 & 111.1 & 135.8 & 118.9 & 129.7 & 7.0 & 121.0 & 121.3 & 109.5 & 134.4 & 116.4 & 125.3 & 6.5 & 0.069 \\
\hline APDI & 82.0 & 82.0 & 71.9 & 92.2 & 77.0 & 86.7 & 5.9 & 79.7 & 79.8 & 68.0 & 93.0 & 75.6 & 83.3 & 5.5 & 0.121 \\
\hline ODI & 74.0 & 74.5 & 57.8 & 98.0 & 69.4 & 79.7 & 8.8 & 78.2 & 78.5 & 65.7 & 95.8 & 73.0 & 82.1 & 7.0 & 0.046 \\
\hline
\end{tabular}

$\mathrm{n}-$ number of persons; $\overline{\mathrm{x}}-$ mean; Me-median; Min—minimum value; Max-maximum value; $\mathrm{Q} 1-$ lower quartile; Q3-upper quartile; SD—standard deviation; * U-Mann-Whitney test.

Table 3. Comparison of IMPA, L1 to LOP, U1 to NA (mm), U1 to NA (deg), L1 to NB (mm), and L1 to NB (deg) scores between the cleft lip and palate group and the cleft lip group.

\begin{tabular}{|c|c|c|c|c|c|c|c|c|c|c|c|c|c|c|c|}
\hline & \multicolumn{14}{|c|}{ Group } & \multirow{3}{*}{$p$-Value } \\
\hline & \multicolumn{7}{|c|}{ Cleft Lip and Palate $(n=30)$} & \multicolumn{7}{|c|}{ Cleft Lip $(n=30)$} & \\
\hline & $\overline{\mathbf{x}}$ & $\mathrm{Me}$ & Min & Max & Q1 & Q3 & SD & $\overline{\mathbf{x}}$ & $\mathrm{Me}$ & Min & Max & Q1 & Q3 & SD & \\
\hline IMPA & 88.2 & 87.3 & 74.2 & 107.3 & 83.6 & 91.9 & 7.9 & 94.7 & 95.1 & 78.7 & 109.1 & 90.5 & 100.5 & 6.8 & $0.001^{* *}$ \\
\hline L1 to LOP & 72.8 & 72.7 & 56.0 & 89.6 & 68.3 & 77.0 & 7.8 & 67.3 & 66.9 & 55.1 & 79.9 & 62.2 & 69.7 & 6.3 & $0.004^{* *}$ \\
\hline U1 to NA (mm) & 1.49 & 1.26 & 0.04 & 5.33 & 0.61 & 2.06 & 1.2 & 1.69 & 1.55 & 0.05 & 4.23 & 0.92 & 2.59 & 1.0 & $0.274 *$ \\
\hline U1 to NA (deg) & 19.6 & 21.3 & 2.4 & 37.5 & 13.4 & 25.0 & 8.6 & 20.4 & 21.8 & -2.4 & 33.5 & 15.5 & 29.8 & 10.1 & $0.530 *$ \\
\hline L1 to NB (mm) & 1.57 & 1.63 & 0.07 & 4.58 & 0.58 & 2.15 & 1.1 & 2.18 & 2.34 & 0.08 & 5.51 & 1.11 & 3.02 & 1.4 & $0.059 * *$ \\
\hline L1 to NB (deg) & 18.1 & 17.2 & 8.3 & 31.9 & 13.1 & 22.5 & 6.6 & 23.1 & 24.0 & 8.9 & 33.1 & 17.7 & 27.8 & 6.5 & 0.004 ** \\
\hline
\end{tabular}

Table 4 presents the comparison of the results obtained for Lip to E-plane and $\mathrm{Na}$ solabial angle against the study groups. Statistically significant results were presented for Upper lip to E-plane $(p=0.002)$, where the mean score for the cleft lip and palate group was -2.32 points ( $\mathrm{SD}=1.5$ points) and for the cleft lip group the mean score was -1.17 points ( $\mathrm{SD}=1.3$ points). Otherwise, no statistically significant differences $(p>0.05)$ were observed (Table 4).

Table 4. Comparison of upper lip to E-plane and nasolabial angle scores between the cleft lip and palate group and the cleft lip group.

\begin{tabular}{|c|c|c|c|c|c|c|c|c|c|c|c|c|c|c|c|}
\hline & \multicolumn{14}{|c|}{ Group } & \multirow{3}{*}{$p$-Value * } \\
\hline & \multicolumn{7}{|c|}{ Cleft Lip and Palate $(\mathrm{n}=30)$} & \multicolumn{7}{|c|}{ Cleft Lip $(n=30)$} & \\
\hline & $\overline{\mathbf{x}}$ & $\mathrm{Me}$ & Min & Max & Q1 & Q3 & SD & $\overline{\mathbf{x}}$ & Me & Min & Max & Q1 & Q3 & SD & \\
\hline $\begin{array}{l}\text { Upper lip } \\
\text { to E-plane }\end{array}$ & -2.32 & -2.28 & -5.25 & 0.47 & -3.17 & -1.37 & 1.5 & -1.17 & -1.07 & -3.88 & 0.98 & -1.95 & -0.14 & 1.3 & 0.002 \\
\hline Nasolabial angle & 95.2 & 94.4 & 55.3 & ca8.7 & 88.0 & 103.9 & 17.1 & 101.7 & 102.4 & 84.1 & 127.1 & 91.5 & 108.7 & 12.0 & 0.095 \\
\hline
\end{tabular}

Table 5 presents the correlations between SNA, SNB and ANB parameters in the cleft lip and palate group. A statistically significant positive correlation was observed between SNA and SNB scores. This indicates that subjects who have a greater degree of maxillary prognathism (SNA) also have a greater degree of mandibular prognathism (SNB). (Table 5). 
Table 5. Summary of correlations between SNA, SNB, and ANB scores in the cleft lip and palate group.

\begin{tabular}{|c|c|c|c|c|c|c|}
\hline & \multicolumn{2}{|c|}{ SNA } & \multicolumn{2}{|c|}{ SNB } & \multicolumn{2}{|c|}{ ANB } \\
\hline & $\mathbf{r}$ & $p$-Value & $\mathbf{r}$ & $p$-Value & $\mathbf{r}$ & $p$-Value \\
\hline SNA & - & - & $0.721 * *$ & $<0.001$ & $0.249^{* *}$ & 0.184 \\
\hline SNB & $0.721 * *$ & $<0.001$ & - & - & $-0.430 *$ & 0.018 \\
\hline ANB & $0.249^{* *}$ & 0.184 & $-0.430 *$ & 0.018 & - & - \\
\hline
\end{tabular}

Table 6 presents the correlations between SNA, SNB and ANB parameters in the cleft lip group. A statistically significant positive correlation was observed between SNA and SNB scores. This indicates that subjects who have a greater degree of maxillary prognathism (SNA) also have a greater degree of mandibular prognathism (SNB) (Table 6).

Table 6. Summary of correlations between SNA, SNB, and ANB scores in the cleft lip group.

\begin{tabular}{cccccccc}
\hline & \multicolumn{2}{c}{ SNA } & \multicolumn{2}{c}{ SNB } & \multicolumn{2}{c}{ ANB } \\
\cline { 2 - 7 } & $\mathbf{r}$ & $p$-Value & $\mathbf{r}$ & $p$-Value & $\mathbf{r}$ & $p$-Value \\
\hline SNA & - & - & $\mathbf{0 . 7 3 6}{ }^{* *}$ & $<\mathbf{0 . 0 0 1}$ & $\mathbf{0 . 4 4 4}{ }^{* *}$ & $\mathbf{0 . 0 1 4}$ \\
\hline SNB & $\mathbf{0 . 7 3 6}{ }^{* *}$ & $<\mathbf{0 . 0 0 1}$ & - & - & $-0.035^{*}$ & 0.855 \\
\hline ANB & $\mathbf{0 . 4 4 4}{ }^{* *}$ & $\mathbf{0 . 0 1 4}$ & $-0.035^{*}$ & 0.855 & - & - \\
\hline r-correlation coefficient; ${ }^{*}$ Pearson's correlation coefficient; * Spearman's Rank correlation coefficient.
\end{tabular}

\section{Discussion}

Based on the above results, all the research hypotheses were confirmed.

The SNA angle is considered correct between 79-85 degrees [20]. Patients with UCLP after lip and palate fusion surgery had a mean score 79.1 degrees. This indicates a tendency towards a retrognathic maxilla. This was also confirmed by the results obtained by Corbo and coauthors [21]. Searching for the cause of reduced maxillary anterior growth in scientific reports, two positions are apparent. Some scientists describe the effect of cleft palate fusion surgery on reduced maxillary anterior growth [22,23]. Others indicate [24] that retrognathic upper jaw also occurs in patients with UCL, suggesting a primary disturbance of growth factors regardless of the surgery performed. Comparing the results obtained by the authors, in which the group of patients with UCL obtained a mean SNA angle value 3 degrees higher than a mean SNA volue in UCLP group, the authors tend to favor the first of these explanations. Moreover, the authors do not confirm the results of Alam [24] and coauthors regarding reduced maxillary anterior growth in UCL patients.

The SNB angle is considered correct in the range of 77-83 degrees [20]. The results present a tendency towards a retrognathic mandible in patients with UCL and UCLP. This is also confirmed by the results of Da Silva Filho and coauthors [25].

In patients with UCLP and UCL, the mean values of the ANB angle indicate the presence of a class II malocclusion. The same findings about patients with unilateral cleft lip and palate were obtained by Romanini and coauthors [26]. The group of patients without cleft-skeletal class II is also the most diagnosed malocclusion in the Polish population [27]. The causes of this abnormality are found, among others, in genetic factors, habits, but also in sagittal and vertical malocclusion disorders, which leads to skeletal compensation in the anterior-posterior plane [28]. With regard to the sagittal plane, crossbite is diagnosed in patients with UCL and UCLP $[29,30]$. In the vertical plane, the results obtained by the authors confirm the tendency of mandibular downward rotation in patients with UCLP [25]. In unoperated patients with unilateral cleft lip and palate the gonial angle presented a vertical growth pattern [31]. There were no differences regarding overjet between the UCL and UCLP groups. ADPI values were less than normal in both groups. Negative overjet was also described by Tindlund and coauthors [32] among UCLP patients before orthodontic 
treatment. The results obtained demonstrate the effect of cleft palate anastomosis in patients with UCLP on overbite, and the dental parameters are described below.

The mean value of the distance of U1 from the NA line was significantly reduced, similarly the angle contained between the NA line and U1 in both groups. Rectroclination of upper incisors in UCLP patients was also described by Burak [33]. The lower incisors were significantly more protruded in patients with cleft lip and palate. The parameters described above are an attempt of the dental compensation that often occurs in skeletal class II. Among patients without cleft, the position of the lower incisors and the inclination of the occlusal plane have been presented to be the most significant in relation to skeletal class II dental compensation [34]. It is also worth mentioning that the researcher cited above, Burak, in his study describes the occurrence of skeletal class III, which is contradicted by the results obtained by the authors.

The analysis of the position of the upper and lower lip in relation to the aesthetic E-line indicates a significant anterior position of the upper lip in patients with cleft lip compared to patients with cleft lip and palate. The E-line was also used in another study to assess the facial attractiveness of individuals with UCLP [35]. It was presented that laypeople, nonorthodontists, rated the face as less attractive if the position of the upper or lower lip was moved away from the E-line. Interestingly, these patients' perceptions were not influenced by the parameters SNA, SNB, ANB, GoGn-SN, and nasolabial angle, which were analyzed by one researcher. Among orthodontists and surgeons-beyond the E-line described-the significance of SNA and GoGn-SN angle on facial perception were confirmed.

\section{Conclusions}

The results present the effect of cleft palate surgery on further forward growth of the maxilla. Decreased ANB angle was present in skeletal class II in patients with UCL and UCLP. The SNB angle was not increased, and the reverse overjet was due to the rectroclination of the upper incisors and protruded lower incisors. Cleft palate surgery affects overbite. Due to the distance of the upper lip from the E-line in UCL patients, they may be perceived as less attractive compared to the patients with cleft lip and palate.

Author Contributions: Conceptualization, N.K.; methodology, N.K.; validation, M.M.; formal analysis, N.K.; investigation, N.K.; resources, N.K.; data curation, N.K.; writing—original draft preparation, N.K.; writing-review and editing, M.M.; visualization, N.K.; supervision, M.M.; project administration, N.K. All authors have read and agreed to the published version of the manuscript.

Funding: The publication was prepared under the project financed from the funds granted by the Ministry of Education and Science in the "Regional Initiative of Excellence" programme for the years 2019-2022, project number 016/RID/2018/19, the amount of funding 9354 023, 74 PLN.

Institutional Review Board Statement: The study was conducted according to the guidelines of the Declaration of Helsinki. Ethical review and approval were waived for this study, due to the nature of the study being a retrospective study basing on already available data.

Informed Consent Statement: Patient consent was waived due to the nature of the study being a retrospective study basing on already available data.

Data Availability Statement: The data presented in this study are available on request from the corresponding author. The data are not publicly available due to a Non-Disclosure Agreement.

Conflicts of Interest: The authors declare no conflict of interest.

\section{References}

1. Shkoukani, M.A.; Chen, M.; Vong, A. Cleft lip-A comprehensive review. Front. Pediatr. 2013, 1, 53. [CrossRef]

2. Różyło-Kalinowska, I.; Różyło, K.T. Wspótczesna Radiologia Stomatologiczna, Rozdz. 27, wyd. I; Wyd. Czelej: Lublin, Poland, 2012.

3. Szelag, J.; Noga, L.; Orłowska, K.; Pałka, L.; Paradowska, A. Analiza wpływu endo- i egzogennych czynników ryzyka w etiologii rozszczepów podniebienia pierwotnego i wtórnego. Dent. Med. Probl. 2006, 43, 556-562.

4. Centers for Disease Control and Prevention. Facts about Cleft Lip and Cleft Palate. Available online: www.cdc.gov/ncbddd/ birthdefects / cleftlip.html (accessed on 21 September 2020). 
5. Lewis, C.W.; Jacob, L.S.; Lehmann, C.U. The primary care pediatrician and the care of children with cleft lip and/or cleft palate. Pediatrics 2017, 139, e20170628. [CrossRef] [PubMed]

6. Harikrishnan, P.; Balakumaran, V. Analysis of Intramaxillary and Mid-Face Skeletal Asymmetry in a Three-Dimensional Model with Complete Unilateral Cleft Lip and Palate. J. Craniofacial Surg. 2018, 29, e759-e762. [CrossRef]

7. Vale, F.; Francisco, I.; Lucas, A.; Roseiro, A.; Caramelo, F.; Sobral, A. Timing of Spheno-Occipital Synchondrosis Ossification in Children and Adolescents with Cleft Lip and Palate: A Retrospective Case-Control Study. Int. J. Environ. Res. Public Health 2020, 17, 8889. [CrossRef] [PubMed]

8. Yoshida, H.; Nakamura, A.; Michi, K.; Wang, G.M.; Liu, K.; Qiu, W.L. Cephalometric analysis of maxillofacial morphology in unoperated cleft palate patients. Cleft Palate Craniofacial J. 1992, 29, 419-424. [CrossRef] [PubMed]

9. Paradowska, A.; Kawala, B.; Szeląg, J.; Szwedowska, A. Wady zębowe u pacjentów z rozszczepem wargi i podniebienia. Czas. Stomatol. 2009, 62, 298-302.

10. Rizell, S.; Bellardie, H.; Karsten, A.; Sæle, P.; Mooney, J.; Heliövaara, A.; Küseler, A.; Brinck, E.; Skaare, P.; Mølsted, K.; et al. Scandcleft randomized trials of primary surgery for unilateral cleft lip and palate: Dental anomalies in 8-year olds. Eur. J. Orthod. 2020, 42, 8-14. [CrossRef]

11. Tan, E.L.; Yow, M.; Kuek, M.C.; Wong, H.C. Dental maturation of unilateral cleft lip and palate. Ann. Maxillofac. Surg. 2012, 2, 158-162. [CrossRef]

12. Shi, B.; Losee, J.E. The impact of cleft lip and palate repair on maxillofacial growth. Int. J. Oral Sci. 2015, 7, 14-17. [CrossRef]

13. Generali, C.; Primozic, J.; Richmond, S.; Bizzarro, M.; Flores-Mir, C.; Ovsenik, M.; Perillo, L. Three-dimensional evaluation of the maxillary arch and palate in unilateral cleft lip and palate subjects using digital dental casts. Eur. J. Orthod. 2017, 39, 641-645. [CrossRef]

14. Ye, B.; Ruan, C.; Hu, J.; Yang, Y.; Ghosh, A.; Jana, S.; Zhang, G. A comparative study on dental-arch morphology in adult unoperated and operated cleft palate patients. J. Craniofac. Surg. 2010, 21, 811-815. [CrossRef] [PubMed]

15. Normando, A.D.; da Silva Filho, O.G.; Capelozza Filho, L. Influence of surgery on maxillary growth in cleft lip and/or palate patients. J. Cranio-Maxillofac. Surg. 1992, 20, 111-118. [CrossRef]

16. Dahl, E. Craniofacial morphology in congenital clefts of the lip and palate. An x-ray cephalometric study of young adult males. Acta Odontol. Scand. 1970, 28, 11+.

17. Jolleys, A. A review of the results of operations on cleft palates with reference to maxillary growth and speech function. Br. J. Plast. Surg. 1954, 7, 229-241. [CrossRef]

18. Procházková, I.; Müllerová, Z. Cephalometric analysis of reverse overjet in patients with total unilateral cleft lip and palate. Acta Chir. Plast. 1989, 31, 48-55.

19. Tinano, M.M.; Martins, M.A.; Bendo, C.B.; Mazzieiro, Ê. Base of the skull morphology and Class III malocclusion in patients with unilateral cleft lip and palate. Dent. Press J. Orthod. 2015, 20, 79-84. [CrossRef] [PubMed]

20. Karłowska, I. Zarys Wspótczesnej Ortodoncji; Wyd. Lek. PZWL: Warszawa, Poland, 2016; p. 133.

21. Corbo, M.; Dujardin, T.; de Maertelaer, V.; Malevez, C.; Glineur, R. Dentocraniofacial Morphology of 21 Patients with Unilateral Cleft Lip and Palate: A Cephalometric Study. Cleft Palate-Craniofacial J. 2005, 42, 618-624. [CrossRef] [PubMed]

22. Ysunza, A.; Pamplona, M.C.; Quiroz, J.; Yudovich, M.; Molina, F.; González, S.; Chavelas, K. Maxillary growth in patients with complete cleft lip and palate, operated on around 4-6 months of age. Int. J. Pediatr. Otorhinolaryngol. 2010, 74, 482-485. [CrossRef] [PubMed]

23. Friede, H.; Johanson, B. A follow-up study of cleft children treated with vomer flap as part of a three-stage soft tissue surgical procedure. Facial morphology and dental occlusion. Scand. J. Plast. Reconstr. Surg. 1977, 11, 45-57. [CrossRef]

24. Alam, M.K.; Alfawzan, A.A.; Haque, S.; Mok, P.L.; Marya, A.; Venugopal, A.; Jamayet, N.B.; Siddiqui, A.A. Sagittal Jaw Relationship of Different Types of Cleft and Non-cleft Individuals. Front. Pediatr. 2021, 9, 651951. [CrossRef]

25. Da Silva Filho, O.G.; Normando, A.D.; Capelozza Filho, L. Mandibular growth in patients with cleft lip and/or cleft palate-The influence of cleft type. Am. J. Orthod. Dentofac. Orthop. 1993, 104, 269-275. [CrossRef]

26. Romanini, R.C.S.; Vedovello, S.A.S.; Raitz, R.; Silva, M.B.F.; Junqueira, J.L.C.; Oliveira, L.B. Craniofacial features of operated unilateral complete cleft lip and palate children: A case control study. Rev. Gaúcha Odontol. 2014, 62, 383-388. [CrossRef]

27. Smiech-Słomkowska, G. Qualitative and quantitative assessment of occlusion in a selected group of children. Czas. Stomatol. 1990, 43, 704-707.

28. Plaza, S.P.; Reimpell, A.; Silva, J.; Montoya, D. Relationship between skeletal Class II and Class III malocclusions with vertical skeletal pattern. Dent. Press J. Orthod. 2019, 24, 63-72. [CrossRef]

29. Reiser, E.; Skoog, V.; Gerdin, B.; Andlin-Sobocki, A. Association between cleft size and crossbite in children with cleft palate and unilateral cleft lip and palate. Cleft Palate Craniofacial J. 2010, 47, 175-181. [CrossRef]

30. Vettore, M.V.; Sousa Campos, A.E. Malocclusion characteristics of patients with cleft lip and/or palate. Eur. J. Orthod. 2011, 33, 311-317. [CrossRef]

31. Naqvi, Z.A.; Shivalinga, B.M.; Ravi, S.; Munawwar, S.S. Effect of cleft lip palate repair on craniofacial growth. J. Orthod. Sci. 2015, 4, 59-64. [CrossRef]

32. Tindlund, R.S.; Rygh, P.; Bøe, O.E. Orthopedic protraction of the upper jaw in cleft lip and palate patients during the deciduous and mixed dentition periods in comparison with normal growth and development. Cleft Palate Craniofacial J. 1993, 30, 182-194. [CrossRef] 
33. Burak, M.Y.; Ponglertnapakorn, A.; Garduño, E.; Calderón, G. Análisis cefalométrico de las características esqueléticas y dentales que presentan pacientes adultos con fisuras labiopalatinas que recibieron tratamiento ortopédico, ortodóncico y/o quirúrgico durante su infancia y adolescencia. Rev. Mex. Ortod. 2015, 3, 22-32. [CrossRef]

34. Anwar, N.; Fida, M. Evaluation of dentoalveolar compensation in skeletal class II malocclusion in a Pakistani University Hospital setting. J. Coll. Physicians Surg. Pak. 2009, 19, 11-16. [PubMed]

35. Papamanou, D.A.; Gkantidis, N.; Topouzelis, N.; Christou, P. Appreciation of cleft lip and palate treatment outcome by professionals and laypeople. Eur. J. Orthod. 2012, 34, 553-560. [CrossRef] 